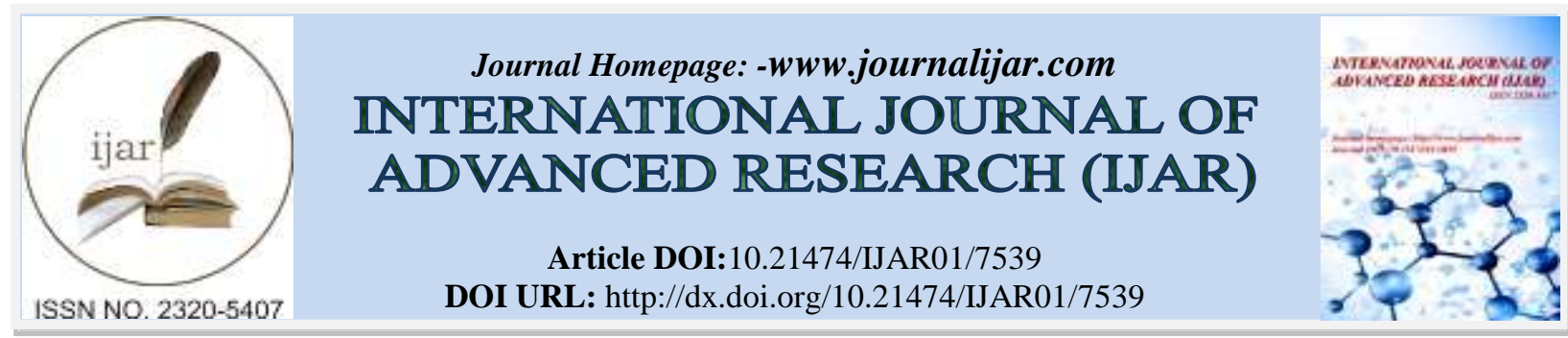

RESEARCH ARTICLE

\title{
STUDY THE EFFECT OF AUTOMATED APAMARGA KSHARSUTRA IN THE MANAGEMENT OF BHAGANDARA.
}

Dr. Bharat M. Rokade and Dr. Umesh A. Vaidya ${ }^{2}$.

1. Associate Professor, Department of Shalyatantra, College of Ayurveda, BharatiVidyapeeth Deemed to be University, Pune, India.

2. Professor, Department of Shalyatantra, College of Ayurveda, BharatiVidyapeeth Deemed to be University, Pune, India.

\section{Manuscript Info}

(.........................

Manuscript History

Received: 11 June 2018

Final Accepted: 13 July 2018

Published: August 2018

\section{Abstract}

Bhagandara is a condition described by various acharya in Ayurveda as a difficult disease to treat. It also considered as Ashtaumahagada means eight grave diseases. Ksharsutra is the prime treatment for Bhagandara. Ksharsutra is a unique and an established procedure for the management of Bhagandara in Ayurveda. This method is well accepted by modern surgeons too. Standardization of ksharsutra is the need of the hour. Therefore decided to work on a standardized form of ksharsutra as automated ksharsutra means machine made ksharsutra, to overcome the drawbacks of traditional ksharsutra.

Materials \& methods- The study was a single blind clinical trial carried out at BharatiVidyapeeth Deemed to be University, College of Ayurved and hospital Pune. The procedure involved ligation of automated ksharsutra through Bhagandara or a fistulous tract, made over a specially designed machine. 20 patients with Bhagandara (fistula in Ano of crypto glandular origin) were selected and treated with ksharsutra. Every time ksharsutra was changed on every $7^{\text {th }}$ day till cutting of tract.

Result- The cutting and healing occurred in all patients treated with automated ksharsutra. Although in this study cutting is faster followed by healing. The average unit cutting time was 5.8 with automated ksharsutra.

Copy Right, IJAR, 2018,. All rights reserved.

\section{Introduction:-}

Bhagandara (Fistula in Ano) at modern parlance is a common anorectal condition prevalent in the populations worldwide and its prevalence is second highest after Arsha (hemorrhoids). In the present study, Ksharasutra application was used in the management of Bhagandara. Although the four modalities for the treatment of Bhagandara have been described, Kshara is the most used form. ${ }^{1-4}$ It promises to be an efficient form of treatment. In modern science, surgery is one of the methods of treating Bhagandara. Kshara Sutra is one of the chief modalities in the treatment of Bhagandara in Ayurvedic science. ${ }^{5-6 .}$

Exploration of the Automated Standardisedksharsutra as a better substitute to traditional ksharsutra is the need of the hour. The rational of the study is to find out an effect of automated ksharsutra in the management of Bhagandara.

Corresponding Author:-Bharat M. Rokade.

Address:-Associate Professor, Department of Shalyatantra, College of Ayurveda, BharatiVidyapeeth 
The Apamarga ksharsutra is well proven to be an effective treatment for fistula in Ano, so we decided to use Apamarga ksharsutra manufactured with specially designed machine which provides firm and smooth layered ksharsutra. It has also unique packaging which avoids loss of kshara from ksharsutra.

\section{Need of the study:-}

All previous research was done on various types of ksharsutra and its comparative study and other form of treatment modalities. But here we explore a new manufacturing method for ksharsutra preparation. Its unique trial ever as far as previous study was concerned.

Traditional ksharsutra may loss its coatings and uniformity while packaging. Also may cause infection due to handling. So we decided to use standardized ksharsutra.

\section{Aim and Objectives:-}

Aim:-

'To study the effect of Automated Standardized Apamargaksharsutra in the management of Bhagandara'.

\section{Objectives:-}

To innovate new method of preparation of ksharsutra.

\section{Hypothesis:-}

Automated ApamargaKsharsutra has better cutting and healing effect.

\section{Materials and methodology:-}

The study/clinical trial was carried out at OPD/IPD of Shalyatantra department of College of Ayurved and hospital, BharatiVidyapeeth Deemed to be University, Pune. The procedure involved ligation of automated ksharsutra through Bhagandara or a fistulous tract, made over a specially designed machine. 20 patients with Bhagandara (fistula in Ano of crypto glandular origin) were selected and treated with ksharsutra. Every time ksharsutra was changed on every $7^{\text {th }}$ day till cutting of tract.

\section{Study group:-}

20 patients (Automated Apamargaksharsutra)

\section{Preparation of drug ksharsutra:}

\section{AutomatedKsharsutra:-}

The ApamargaKsharsutra prepared by automated machine at Indu pharma (GMP and ISO certified), Jejuri MIDC, Pune.

The contents of Standardised Ksharsutra are -

1. Snuhikshira (Euphorbia nerifolia)

2. Apamargakshara (Achyranthusaspera)

3. Haridrachurna (Curcuma longa)

Preparation of ApamargaKsharasutra comprises smearing a long barber's linen thread no. 20 sequentially with fresh latex (Snuhikshira) of Euphorbia nerifolia Linn, a specially prepared alkaline powder known as Apamargakshara from AchyranthusasperaLina, and powder of dried rhizomes of Turmeric (Haridra) curcuma longa lina.

The thread coated with an automated machine (specially designed for Ksharsutra preparation) first with the latex eleven times, followed by seven alternate coating of latex and Apamargakshara and dried. In the final phase, three alternate coating of latex and turmeric powder are given and the thread will be dried and sterilized with UV rays. The threads thus prepared enveloped in a unique packing so that kshara will be maintained at Ksharsutra and loss of kshara will be avoided.

Advantage of automated made Ksharsutra will be smooth, firm and uniform coatings of Snuhikshira, Apamargakshara and Haridra. It fascilates the cutting and healing property of ksharsutra more effectively than manually made Ksharsutra. 

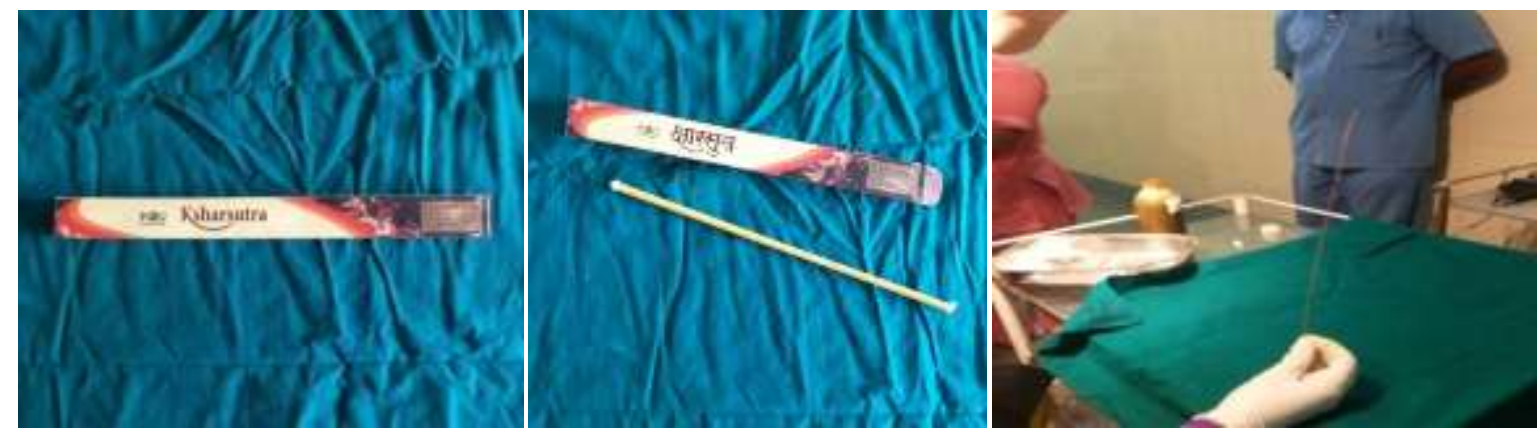

\section{Method of ksharsutra ligation:-}

1. Pre-operative preparation

2. Operative procedure ksharsutra ligation under spinal Anesthesia

3. Postoperative measures

4. Ksharsutra Changing on $7^{\text {th }}, 14^{\text {th }} 21^{\text {th }} \& 28^{\text {th }}$ days of follow up till healing of tract.

\section{Selection and exclusion criteria of study participants Inclusion criteria:-}

1. Patients having anal fistula.

2. Selection was irrespective of sex, religion \& socio- economical class.

3. Age between 15 to 60 years.

\section{Exclusion criteria:-}

1. Patients having bleeding disorders, patients on anti -coagulation drugs and Ca rectum.

2. Patient of age below 15 year $\&$ above 60 years were excluded.

3. Pregnant women.

4. Chronic or acute ulcerative colitis.

5. Intestinal and pelvic malignancies.

6. Veneral diseases and HIV.

7. Multiple fistulae originating mainly due to Tuberculosis.

8. Crohn's disease.

9. Uncontrolled DM

\section{Criteria of Assessment:-}

Subjective parameters

PAIN - By visual analogue scale

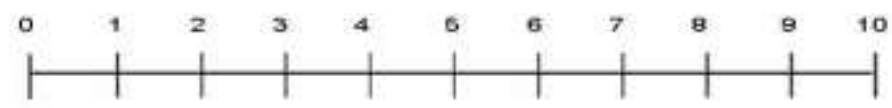

\section{ITCHING}

No Itching

Mild \& occasional

Moderate \& occasional

Moderate \& Frequent

Severe \& continuous
0

1

2

3

4 


\section{Objective parameters}

\section{A) DISCHARGE}

$\begin{array}{lc}\text { No Discharge } & 0 \\ \text { Mild (If wound wet } 1 \mathrm{~cm} \text { gauze piece) } & 1 \\ \text { Moderate (If wound wet } 2 \mathrm{~cm} \text { gauze piece) } & 2 \\ \text { Severe (If wound wet more than } 2 \mathrm{~cm} \text { gauze piece) } & 3 \\ \text { Excruciating (continuous \& profuse) } & 4\end{array}$

0

1

2

3

4

\section{B ) NATURE OF DISCHARGE}

$\begin{array}{ll}\text { Blood } & 0 \\ \text { Serous } & 1 \\ \text { Purulent } & 2\end{array}$

\section{C) LENGTH OF TRACT}

Initially length of tract is measured with the help of probe and length of thread/ksharsutra within the tract then on every follow up length of previous ksharsutra within tract is measured with scale and considered as length of tract.

\section{D) UCT ( UNIT CUTTING TIME)}

UCT $=$ Total No. of days taken to cut through / Initial length of tract in cms

$$
\text { = Days } / \text { cms. }
$$

\section{Investigations}

Routine hematological, biochemical, urine and stool examinations were done to rule out the pathological conditions mentioned above.

Radiological examinations

1. X-ray chest PA view (if required)

2. Fistulography (in high anal and recurrent fistulae)

3. MR fistulogram (if required and in selected cases)

Follow Up:-

Follow up is taken on $1^{\text {st }}, 7$ th $\& 14^{\text {th }}$ days and observations recorded in a tabular form.

Observations -

Table 1- Incidence of age

\begin{tabular}{|c|c|}
\hline Age group in years & No of patients. \\
\hline Upto $20 \mathrm{yrs}$ & 02 \\
\hline $21-30 \mathrm{yrs}$ & 06 \\
\hline $31-40 \mathrm{yrs}$ & 08 \\
\hline $41-50$ yrs & 02 \\
\hline 51 and above & 02 \\
\hline TOTAL & 20 \\
\hline
\end{tabular}


Table 2- Incidence of Sex

\begin{tabular}{|c|c|}
\hline Sex & No of patients. \\
\hline Male & 13 \\
\hline Female & 07 \\
\hline TOTAL & 20 \\
\hline
\end{tabular}

Table 3- Types of Bhagandara

\begin{tabular}{|c|c|}
\hline Types of Bhagandara & No of patients. \\
\hline Shataponaka & 02 \\
\hline Ushtragreeva & 03 \\
\hline Parisravi & 11 \\
\hline Shambhukavarta & 03 \\
\hline Unmargi & 01 \\
\hline TOTAL & 20 \\
\hline
\end{tabular}

Table 4- Types of Fistula in Ano

\begin{tabular}{|c|c|}
\hline Types of & No of patients. \\
\hline Fistula in Ano & 03 \\
\hline Sub cutaneous & 05 \\
\hline Sub mucous & 10 \\
\hline Low anal & 02 \\
\hline High anal & 20 \\
\hline TOTAL & 20 \\
\hline
\end{tabular}

Table 5- Incidence of new and old cases

\begin{tabular}{|c|c|}
\hline New and old(recurrence) cases & No of patients. \\
\hline New cases & 16 \\
\hline Old/recurrent cases & 04 \\
\hline TOTAL & 20 \\
\hline
\end{tabular}

Table 6 - Incidence of clockwise position of external opening

\begin{tabular}{|c|c|}
\hline Clockwise position of external opening & $\begin{array}{c}\text { No of patients. } \\
\text { A- Group (standardized ) }\end{array}$ \\
\hline 1 & 00 \\
\hline 2 & 01 \\
\hline 3 & 01 \\
\hline 4 & 02 \\
\hline 5 & 04 \\
\hline 7 & 03 \\
\hline 8 & 01 \\
\hline 9 & 02 \\
\hline 10 & 02 \\
\hline 11 & 01 \\
\hline 12 & 02 \\
\hline TOTAL & 01 \\
\hline
\end{tabular}

Table 7 - Incidence of initial length of tract

\begin{tabular}{|c|c|}
\hline Initial length of tract & No of patients. \\
\hline Up to $5 \mathrm{~cm}$ & 12 \\
\hline $5.1-10 \mathrm{~cm}$ & 04 \\
\hline $10.1-15 \mathrm{~cm}$ & 03 \\
\hline Above $15 \mathrm{~cm}$ & 01 \\
\hline TOTAL & 20 \\
\hline
\end{tabular}


Table 8 - Incidence of UCT with different clockwise position

\begin{tabular}{|c|c|}
\hline Clockwise position & UCT \\
\hline 1 & 5.7 \\
\hline 2 & 6.2 \\
\hline 3 & 5.5 \\
\hline 4 & 5.8 \\
\hline 5 & 5.5 \\
\hline 6 & 5.7 \\
\hline 7 & 5.3 \\
\hline 8 & 6.5 \\
\hline 9 & 7.2 \\
\hline 10 & 5.8 \\
\hline 11 & 5.6 \\
\hline 12 & 6.4 \\
\hline TOTAL & 20 \\
\hline
\end{tabular}

Table 9 - Average UCT Standardized ksharsutra A Group

\section{Discussion and conclusion:-}

1. Incidence of fistula in Ano was more common in the age group 31-40 years.(Table no.1)

2. Males were more prone to Bhagandara i.e. fistula in Ano as compared to females. (Table no.2)

3. In this study maximum patients having parisravibhagandar were recorded as compared to other type of Bhagandara. (Table no.3)

4. Maximum patients of low anal fistula were recorded during the study as far as types of fistula are concerned. (Table no.4)

5. New or fresh cases were more in numbers as compared to old or recurrent cases. (Table no.5)

6. 5 clock position of external opening was found in maximum 8 patients compared to other position.(Table no.6)

7. Initial length of tract i.e. up to $0-5 \mathrm{~cm}$ was recorded in maximum 22 patients. (Table no.7)

8. Maximum UCT was 7.2 at 9 o' clock position\& minimum UCT was 5.3 at 7 o' clock position. (Table no.8)

\section{Conclusion:-}

Average UCT of Automated Apamarga ksharsutra was 5.8. It shows good cutting effect followed by healing in spite of simultaneous cutting and healing effect.

\section{References:-}

1. AcharyaSushruta, SushrutaSamhita, Dalhana, Nibandhasangrahacommentary,Edited by JadavjiTrikamjiAcharya and Naarayana Ram Acharya; Varanasi: Chaukhambha Sanskrit Sansthan; Reprint 2013; Nidaanasthana 4/3-12, Pp 824, p280-282

2. AcharyaSushruta, SushrutaSamhita, Dalhana, Nibandhasangrahacommentary,Edited by JadavjiTrikamjiAcharya and Naarayana Ram Acharya; Varanasi: Chaukhambha Sanskrit Sansthan; Reprint 2013; Chikitsasthana 17/29-33, Pp 824, p468.

3. AcharyaAgnivesha, CharakaSamhita, revised by Charaka\&Dridabala, with Ayurveda Dipika commentary of Chakrapanidatta, Edited by JadavjiTrikamjiAcharya; Varanasi: ChaukhambhaPrakashan; Reprint 2013; Chikitsasthana 12/96- 97, Pp738, p490.

4. AcharyaVruddhaVagbhata, AshtangaSamgraha; with the Sasilekha commentary by Indu, Prologue by Prof.JyotirMitra, Edited by Dr. Shivprasad Sharma; Varanasi: Chowkhamba Sanskrit series office; Reprint 2008; Uttarasthana 33/2-44, Pp 965, p797-803

5. ShriChudamaniMishra,Rasakamdhenu with Suvritta Hindi Commentry, Edited by AcharyashriGulraj Mishra; Varanasi: ChowkhambaOrientalia; Chikitsaadhikar 49/1-2,Pp 329

6. Chakrapanidatta, Chakradatta; with the Vaiyaprabha Hindi Commentary by Dr.IndradevaTripathi, Edited by Prof. RamanathDwivedy; Varanasi: Chaukhambha Sanskrit Bhawan; Reprint2010; Nadivranachikitsa/12$13, \mathrm{p} 269-272$. 